ADAM DOMALEWSKI

Instytut Filmu, Mediów i Sztuk Audiowizualnych Uniwersytet im. Adama Mickiewicza w Poznaniu
Images

vol. XXVII/no. 36

Poznań 2020

ISSN 1731-450X

\title{
Między minimalizmem a melodramatem. Przestrzeń filmowa w kinie rumuńskiej nowej fali
}

\begin{abstract}
Domalewski Adam, Między minimalizmem a melodramatem. Przestrzeń filmowa w kinie rumuńskiej nowej fali [Between minimalism and melodrama. Film space in the Romanian New Wave cinema]. "Images" vol. XXVII, no. 36. Poznań 2020. Adam Mickiewicz University Press. Pp. 71-92. ISSN 1731-450X. DOI 10.14746/i.2020.36.05.

The starting point for considering the means of creating and designing a film space in Romanian New Wave cinema is the thesis that Romanian film art in the 21st century is an artistic response to the times of communism and that images of the post-socialist architectural space - their multi-faceted functionalization in film mise-en-scéne - are the key method of evoking memories of the past. The article discusses, via the example of movies by Crisitian Mungiu, Corneliu Porumboiu and Cristi Puiu, (1) ways of depicting the "closing" of film characters in the cramped interiors of their apartments and (2) film images of individuals' alienation in public spaces, both of them allusively referring to the times of the oppressive Nicolae Ceaușescu regime. The most important cinematographic devices used by the authors of the Romanian New Wave cinema include: seemingly static shots, which, however, are filmed with a camera that is constantly gently moving and observing, and tableau shots. A common feature of all the considered works is the panopticism of the film world: the private and public spaces designed in them easily become a place of constant, panoptical observation. In the summary, the author remarks on and briefly discusses the coexistence of the aesthetics of minimalism / realism with the melodramatic elements in the cinematic structure of Romanian New Wave films.
\end{abstract}

KEYWORDS: Romanian cinema, communism and motion pictures, motion pictures - semiotics, motion pictures - political aspects

Dążenie do objęcia wspólnym terminem oraz panoramicznego opisu kina rumuńskiego jako ważnego zjawiska w europejskiej sztuce filmowej pojawiło się wkrótce po pierwszych spektakularnych festiwalowych sukcesach rumuńskich filmów na początku nowego stulecia. Już w 2007 roku krytyk filmowy Alex Leo Şerban zaczął pisać o nowym kinie w swoim kraju[1], równocześnie pojawiło się też określenie rumuńska nowa fala (Christina Stojanova jako jego prekursora wskazuje Mahaia Fulgera), spopularyzowane nieco później przez Doru Popa[2]. Tak jak zwykle w takich przypadkach bywa, wśród badaczy nie ma zgody co do używanej nomenklatury, tym niemniej z perspektywy czasu łatwiej o systematyczne rozróżnienia. Przekonującą propozycję

[1] Ch. Stojanova, Introduction, [w:] The New Romanian Cinema, red. Ch. Stojanova, D. Duma, Edinburgh 2019, s. 3.

[2] Zob. D. Pop, Romanian New Wave Cinema. An introduction, Jefferson 2014. Badacz do grona „nowofa- lowych" reżyserów zalicza przede wszystkim Cristiego Puiu, Mariana Crișana, Tudora Giurgiu, Cristiana Mungiu, Radu Munteana, Cătălina Mitulescu, Corneliu Porumboiu i Florina Șerbana. 
przedstawiła Anna Batori, która twierdzi, że nowe kino rumuńskie jest pojęciem szerszym aniżeli pojawiające się w podobnych kontekstach sformułowanie rumuńska nowa fala, opisujące jedynie realistyczno-minimalistyczną, autorską część produkcji filmowej. Batori w swojej książce poświęconej przestrzeni w kinie rumuńskim i węgierskim stawia przy tym tezę, iż głównym tematycznym spoiwem nowej fali kina rumuńskiego są bezpośrednie lub pośrednie odwołania do socjalistycznej przeszłości doby Ceaușescu[3]. Podzielając ten punkt widzenia, przyjmuję zatem, że nową falę kina rumuńskiego jako nurt artystyczny rozpatrywać należy na trzech co najmniej poziomach - formalnym, tematycznym i ideowym. Tworzą ją filmy, które niewątpliwie łączy szereg wyznaczników estetycznych, opisywanych jako inscenizacyjny minimalizm i społeczny realizm, a więc: jednowątkowość, trzyczęściowa struktura dramaturgiczna, zachowanie fabularnej chronologii, brak muzyki niediegetycznej, operowanie długimi ujęciami, zawężenie czasu akcji - często do klasycznej formuły 24 godzin, niewielka liczba postaci itd. Niektóre z tych cech rumuńskiej nowej fali - wraz z jej zarysem historycznym - szczegółowo omawia Christina Stojanova, badaczka przypisuje je jednak - nieco na wyrost - całemu nowemu kinu rumuńskiemu. Stojanova proponuje przy tym określenie realizm egzystencjalny, opisujące dominującą, jej zdaniem, w nowym kinie rumuńskim tematykę etycznej odpowiedzialności jednostki w duchu ironicznego lub tragicznego indywidualizmu[4]. Szersza charakterystyka nurtu wyłoni się w moim zamierzeniu z dalszych części pracy.

Inna kwestia, która domaga się wyjaśnienia już na wstępie, dotyczy dynamiki rozwoju rumuńskiej kinematografii. Wydaje się, że ostatnie piętnaście lat, na które przypadły liczne międzynarodowe i artystyczne sukcesy rumuńskich twórców, umownie podzielić można na dwa okresy: od roku 2005 do 2010 oraz drugą dekadę XXI wieku. Podczas pierwszego z nich ukształtował się kanon nowej fali kina rumuńskiego[5] wraz z jej charakterystyczną filmową estetyką. Filmy te ze szczególną intensywnością powracały do tematyki komunizmu oraz postkomunizmu, choć czyniły to zwykle za pomocą intymnych historii ograniczonych do niewielkiego kręgu osób. Te właśnie obrazy będą stanowiły główny przedmiot mojego zainteresowania. Wraz z upływem czasu i rosnącą pozycją kina rumuńskiego na świecie coraz większy udział w strukturze filmowej produkcji zaczęły mieć międzynarodowe koprodukcje. Kolejne festiwalowe sukcesy filmów takich jak: Pozycja dziecka (Poziţia copilului, reż. C.P. Netzer, 2013), Skarb (Comoara, reż. C. Porumboiu, 2015), Egzamin (Bacalaureat, reż. C. Mungiu, 2016) czy Touch Me Not (reż. A. Pintilie, 2018), choć nadal zakorzenione w rumuńskiej rzeczywistości, są dziełami podejmującymi bardziej uniwer-

[3] A. Batori, Space in Romanian and Hungarian Cinema, Cham 2018, s. 67.

[4] Zob. Ch. Stojanova, op.cit., s. 1-20.

[5] D. Pop, Making and breaking the new wave canon in Romanian cinema, [w:] Cultural Studies Approa- ches in the Study of Eastern European Cinema. Spaces, bodies, memories, red. A. Virginás, Cambridge 2016, s. $268-288$. 
salne tematy (winy, odpowiedzialności, konsumpcjonizmu, korupcji, cielesności itd.), w dodatku w swojej filmowej formie mającymi coraz mniej wspólnego z rozwiązaniami wypracowanymi wcześniej na potrzeby rumuńskiego minimalizmu. Wyjątek w tym gronie stanowi film Mungiu, którego poetyka nie odbiega od poprzednich filmów reżysera. Mungiu, Puiu i Porumboiu - jak diagnozuje Doru Pop - w ostatnich filmach dokonują swoistej autokanonizacji, kopiując rozwiązania i strategie autorskie, które przyniosły im sukces[6]. Jednak już Adina Pintilie i Radu Jude przejawiają dużo bardziej ambiwalentny stosunek do osiągnięć poprzedników, a filmy takie jak Aferim! (reż. R. Jude, 2015) i Nie obchodzi mnie, czy przejdziemy do historii jako barbarzyńcy (Îmi este indiferent daca în istorie vom intra ca barbarii, reż. R. Jude, 2018) wprowadzają tematykę polityczną zupełnie otwarcie i wprost - inaczej niż zwykli czynić to „kanonizowani” autorzy.

Wspomniana Anna Batori uznaje, że rumuńska sztuka filmowa w XXI wieku jest artystyczną reakcją na czasy komunizmu, a kluczowym sposobem, za pomocą którego ewokuje pamięć o przeszłości, są reprezentacje postsocjalistycznej przestrzeni architektonicznej - ich wieloaspektowe sfunkcjonalizowanie w filmowej mise-en-scéne[7]. Zdaniem Batori struktura przestrzenna filmów zaliczanych do rumuńskiej nowej fali ujawnia opresję dawnego reżimu, a także wskazuje na sięgające współczesności przedłużenia tamtego systemu[8]. W niniejszym artykule, na przykładzie filmów Cristiego Puiu, Crisitiana Mungiu oraz Corneliu Porumboiu, postaram się ukazać sposoby kreowania przestrzeni filmowej w nowej fali kina rumuńskiego: prześledzę szereg zabiegów formalnych, za pomocą których twórcy tego kina podkreślają znaczenie przestrzeni architektonicznej w swoich dziełach. Filmowane przez nich budynki, przestrzenie publiczne i wnętrza wydatnie wpływają na prezentowane relacje społeczne i sytuację bohaterów. Negatywne nacechowanie przestrzeni otaczającej postaci wiąże się w tych obrazach zwykle $\mathrm{z}$ ustaloną, konsekwentną pracą kamery oraz konkretnymi rozwiązaniami operatorskimi, budującymi zamkniętą przestrzeń diegetyczną - chcę podać przykłady tego rodzaju zabiegów, typowych dla nowej fali kina rumuńskiego. Na koniec zaś podejmę kwestię możliwych związków między filmowym minimalizmem a melodramatem - przypadek kina rumuńskiego dostarcza tu ciekawego materiału do rozważań, także ze względu na udział przestrzeni filmowej w ustanawianiu obu tych konwencji.

Sztandarowe dzieło całego nurtu - 4 miesiace, 3 tygodnie i 2 dni Panoptyczne tableau (4 luni, 3 săptămâni şi 2 zile, 2007) Cristiana Mungiu, czyli nagrodzona Złotą Palmą w Cannes opowieść o dwóch studentkach, noszących imiona Găbitą i Otilia, które w 1987 roku zmierzają do przeprowadzenia nielegalnej aborcji - to przykład filmu bezpośrednio wskrzeszające-

[6] Ibidem, s. 268-277.

[8] Ibidem.

[7] A. Batori, op.cit., s. 73. 
go rzeczywistość późnych rządów Ceaușescu, a jednocześnie dzieło w dojrzałej, mistrzowskiej formie prezentujące cechy minimalistycznej estetyki rumuńskiej nowej fali. Film składa się z długich, wymagających wielkiego wysiłku realizacyjnego[9], precyzyjnie zakomponowanych ujęć - często pozornie statycznych, które jednak filmowane są kamerą nieustannie delikatnie poruszaną, w dokumentalny sposób zaświadczającą o swojej obecności, obserwującą. Uwolnienie kamery ze statywów nie jest oczywiście w kinie europejskim niczym nowym; na potrzeby rumuńskiej nowej fali „wynalazł” je zresztą Cristi Puiu w Śmierci pana Lăzărescu (Moartea domnului Lăzărescu, 2005), niemniej w filmie Mungiu przybiera ono postać skrajnie sformalizowaną, determinującą sposób prowadzenia narracji. Innym wyznacznikiem estetyki obrazu, i zarazem pochodną pracy kamery, są ujęcia w stylu tableau, charakterystyczne również dla innych twórców nowej fali[10]. Ágnes Pethő opisuje je w kontekście twórczości Corneliu Porumboiu jako „frontalne długie ujęcia, filmowane mniej lub bardziej statyczną kamerą, oferujące wrażenie oglądania obrazu, ruchomej fotografii" [11], ustanawiające przy tym specyficzną relację między widzem a ekranowym obrazem. Zdaniem badaczki tableau ma dwojaką naturę: z jednej strony, ze względu na utrzymywanie przez dłuższy czas ustalonej odległości między kamerą a filmowaną frontalnie sceną, pozwala widzowi na zdystansowanie i głębszy namysł nad ekranowym przedstawieniem, z drugiej zaś może wywołać efekt zaabsorbowania obrazem i tym samym wzmocnić „wrażenie rzeczywistości (sensation of reality)" [12]. Filmowe tableau sprawdza się więc zarówno w podkreślaniu sztuczności, jak i realności wykreowanego świata; jest techniką, za pomocą której wykreować można poczucie bycia zarazem na zewnątrz i wewnątrz oglądanych wydarzeń[13]. Mungiu we współpracy z autorem zdjęć, Olegiem Mutu, używa obu wspomnianych technik operatorskich razem, co uprzywilejowuje efekt zaabsorbowania widza i buduje wrażenie niezwykle intymnego obserwowania, wręcz podglądania bohaterek filmu. Praca kamery uwypukla zatem bezradność Găbity i Otilii, gorączkowo poszukujących wyjścia z kolejnych kryzysowych sytuacji: problemów z rezerwacją pokoju, natarczywością lekarza nielegalnie przeprowadzającego aborcję (ukrytą

[9] Ioana Uricaru podaje informację, że nakręcenie każdego długiego ujęcia w filmie zajmowało od pół dnia zdjęciowego do nawet dwóch dni. Zob. eadem, No Melo: minimalism and melodrama in the new Romanian cinema, [w:] The New Romanian Cinema..., S. 51.

[10] Zob. Á. Pethö,'Exhibited space' and intermediality in the films of Corneliu Porumboiu, [w:] The New Romanian Cinema..., s. 65-79.

[11] Ibidem, s. 66.

[12] Ibidem, s. 67.

[13] Warto przy tym dodać, że z filmowych tableaux swój znak rozpoznawczy uczynili tacy wielcy twórcy światowego kina, jak Pier Paolo Pasolini czy Siergiej
Paradżanow. W ich przypadku ta technika inscenizacyjno-operatorska pełniła inne jeszcze funkcje, chociażby „archetypizowania” świata przedstawionego, który (dzięki jej zastosowaniu) zdaje się egzystować poza czasem. W dojrzałym stylu Paradżanowa filmowe tableau uzyskiwało coraz większą autonomię w obrębie dzieła filmowego i sprawiało, że jego $\mathrm{w}$ filmach coraz trudniej było wyłonić tradycyjnie budowane łańcuchy akcji. Zamiast tego widzowie otrzymywali tajemnicze ciągi silnie zmetaforyzowanych i unieruchomionych w obrębie pojedynczego kadru obrazów. Zob. J. Steffen, The Cinema of Sergei Parajanov, Madison 2013, s. 63, 103. 
pod płaszczykiem solidarności[14]), wreszcie koniecznością pozbycia się płodu.

Bohaterki filmu, znajdujące się w coraz większym potrzasku, wydają się zamknięte nie tyle nawet w filmowanych wnętrzach (akademika, mieszkania, hotelu), co uwięzione w pieczołowicie zrekonstruowanym, nieprzyjaznym świecie. Warto zauważyć, że motyw uwięzienia pojawia się już w otwierającym film obrazie złotej rybki pływającej w akwarium. Anna Batori sposób funkcjonowania przestrzeni zarówno w 4 miesiacach..., jak i w innych filmach rumuńskiej nowej fali określa mianem wertykalnego zamknięcia[15]. Autorka w prowadzonych analizach zwraca uwagę na architektoniczne bądź scenograficzne domknięcie przestrzeni znajdującej się za aktorami, które sprawia, że wydają się oni nie tylko pozbawieni możliwości ucieczki, ale także wyalienowani. Przykładów tego typu inscenizacji w obrazie Mungiu można podać wiele: choćby rozmowa Otilii z jej chłopakiem na uczelnianym korytarzu, a więc $\mathrm{w}$ przestrzeni publicznej, toczy się, gdy za bohaterami znajduje się przeszklenie oddzielające ich od zatłoczonej klatki schodowej.

Wszystkie użyte w filmie wnętrza i plenery pogłębiają poczucie beznadziejnego położenia i osamotnienia bohaterek, a jednocześnie wskazują na opresyjność otaczającej je rzeczywistości. Zgrzebność urządzenia pokoju studenckiego $\mathrm{w}$ akademiku oraz kwitnący tam handel przypominają o dokuczliwym niedostatku produktów codziennego użytku. Nędzne hotele oraz opryskliwość pracującej w nich obsługi odnoszą się z kolei do niedorozwoju sektora usług w gospodarkach socjalistycznych, będącego kolejnym źródłem poniżenia ludności. Wizyta Otilii na imieninach matki jej chłopaka, z kulminacyjną sceną posiłku nakręconą w jednym ujęciu w stylu tableau, uzmysławia podziały klasowe (dziewczyna ma pochodzenie chłopskie, Adi wywodzi się $\mathrm{z}$ inteligencji) istniejące w komunistycznej Rumunii. Bohaterka spotyka się z pogardliwym potraktowaniem, które - co gorsza - nie wydaje się rozmyślne; jest raczej głęboko uwewnętrznionym przekonaniem o własnej pokoleniowej i klasowej wyższości, choć jest to wyższość socjalistycznej elity społecznej zajmującej ciasne mieszkanie na podmiejskim blokowisku. W 4 miesiacach, 3 tygodniach i 2 dniach Cristian Mungiu w niemal każdej scenie czyni aluzje do rozmaitych dysfunkcji systemu, w którym umieszczona jest akcja filmu.

Podobną strategię, choć jeszcze bardziej zakamuflowaną, zaobserwować można w filmie Policjant, przymiotnik (Politist, adjectiv, 2009) Corneliu Porumboiu. Obraz ten rozgrywa się współcześnie w Vaslui, niewielkim, rodzinnym mieście reżysera - tym samym, w którym

[14] Jak zauważa Claudiu Turcuş, zachowanie ginekologa o imieniu Bebe jest perwersyjne: oscyluje on między opanowaniem a agresją, zasłaniając się fałszywym poczuciem solidarności (wszyscy uczestniczący w aborcyjnym procederze ryzykują karą więzienia). Udawana empatia jest tylko amoralną strategią, by czerpać korzyści finansowe i seksualne. C. Turcuş, Paradigms of rememoration in postcommunist Romanian cinema, [w:] Cultural Studies Approaches..., S. $230-231$.

[15] A. Batori, op.cit., s. 11-13, 136-138. 
osadzona była akcja jego debiutanckiego filmu 12:08 na wschód od Bukaresztu (A fost sau n-a fost?, 2006)[16]. Tytułowy policjant, około trzydziestoletni Cristi, prowadzi czynności w sprawie trojga nastolatków podejrzewanych o posiadanie narkotyków. W celu zebrania materiałów dowodowych na polecenie przełożonych obserwuje Alexa, Doinę i Victora. Andrea Virginás pisze:

W filmie Policjant, przymiotnik świat diegetyczny jest w większości konstruowany na zewnątrz, w ulicznych lokacjach, które wydają się prawdziwe - i jako takie są kategoryzowane przez osoby znające postkomunistyczną przeszłość Rumunii - [rozpoznające - przyp. A.D.] ponure bloki mieszkalne, nierówne chodniki, zardzewiałe ogrodzenia i ogólną jesienną atmosferę[17].

Faktycznie, bohater porusza się po Vaslui w czasie pochmurnych jesiennych dni, krążąc między kilkoma nieatrakcyjnymi miejscami: szkołą, budynkiem policji, ulicą przed domem Victora oraz własnym mieszkaniem. Jednakże wnętrza tych budynków - ich rozplanowanie, urządzenie i wygląd - także pełnią w filmie istotną funkcję diegetyczną. Jak słusznie zauważa Anna Batori, filmowane ulice, budynki i pomieszczenia „nie noszą śladu wizualnego odniesienia do kapitalistycznej teraźniejszości" [18]. Poza typowymi blokami z wielkiej płyty oraz szarymi ulicami niewielkiego Vaslui oglądamy zatem pokoje będące miejscem pracy policjantów, długie i wąskie korytarze komisariatu, po których porusza się Cristi, oraz wnętrze jego mieszkania - wszystkie zaprojektowane jeszcze w czasach socjalizmu i wciąż wypełnione przedmiotami wówczas wyprodukowanymi. Uwagę przykuwają zwłaszcza stare meble i urządzenia: krzesła, stoły, biurka, sofy, telefony i szafy pancerne. Nawet jeśli w pomieszczeniach tych dostrzec można sprzęty należące już do nowej, cyfrowej epoki medialnej, są one $\mathrm{z}$ reguły przestarzałe lub nieużywane - duże, pożółkłe monitory kineskopowe w biurze policji są tego dobrym przykładem. Ágnes Pethő stwierdza, iż wizualne po-

[16] Debiut Porumboiu - jeden z klasycznych tytułów rumuńskiej nowej fali - zalicza się do grona filmów współczesnych explicite odnoszących się do komunistycznej przeszłości, a dokładnie - do czasu rewolucyjnego przełomu. 22 grudnia 2005 roku, 16 lat po rozpoczęciu bukareszteńskich protestów, które doprowadziły do obalenia Ceaușescu, dziennikarz pracujący w lokalnej telewizji zaprasza do studia dwóch mężczyzn, Emanoila Pişcoci i Tiberiu Mănescu, uchodzących za byłych opozycjonistów. Jak pisał Rafał Syska, „Mănescu, dziś pijak i dłużnik, [...] ze swadą opowiada, jak to przed południem 22 grudnia zorganizował na placu przed ratuszem demonstrację. Jeśli zdarzyło się to, zanim Ceaușescu uciekł z Bukaresztu, to mieszkańcy miasteczka mogą czuć się bohaterskimi rewolucjonistami, ale jeśli kilkanaście minut później, to - jak twierdzi prowadzący - do rewolucji tylko się przyłączyli. Atmosfera w studiu gęstnieje i zamiast w okolicznościową laurkę program przekształca się w posępną wizję degrengolady, obojętności i apatii [...]”. R. Syska, (Re)konstruowanaie pamięci o Rewolucji w nowym kinie rumuńskim, „Images. The International Journal of European Film, Performing Arts and Audiovisual Communication" 2015, vol. XVII, nr 26, s. 9. Film Porumboiu w ironiczny i gorzki sposób komentował w ten sposób niegasnące w Rumunii spory dotyczące rzeczywistego przebiegu grudniowych wydarzeń, w tym odpowiedzialności armii za śmierć kilkuset osób w trakcie rewolucyjnego zrywu.

[17] A. Virginás, Traces of genre in new Romanian cinema: A narrow path for a small entity?, [w:] The New Romanian Cinema..., s. 189 (przekł. własny).

[18] A. Batori, op.cit., s. 133. 
dobieństwo między budynkami szkoły, policji i mieszkaniem Cristiego odczytać należy jako zamierzoną ironię reżysera[19].

Wyeksploatowanie budynków - inną ich cechę negatywnie wpływającą na funkcjonowanie postaci - Corneliu Porumboiu umiejętnie podkreśla także w sferze audialnej: drzwi skrzypią, gdy bohaterowie je otwierają, hałasują także zdezelowane meble. Typowa dla nowego kina rumuńskiego cisza[20], przerywana jedynie niepożądanymi odgłosami przedmiotów, kreuje ponury i złowrogi nastrój. W aspekcie wizualnym jest on również podkreślony - dominującym kolorem używanym przez Porumboiu na tle wyłaniających się zewsząd szarości i beżów jest ciemnoniebieski. Tej barwy są obiekty koncentrujące uwagę widzów: samochód przed domem Victora, segregatory wypełniające policyjne biura, kurtka dżinsowa Cristiego itd. Kojarzący się z policją granatowy kolor nieprzypadkowo stanowi wizualny lejtmotyw w świecie przedstawionym filmu. Zarówno w planie fabularnym - w swojej narracyjnej strukturze, jak i na poziomie skojarzeń historycznych w jego centrum znajduje się bowiem akt obserwowania[21]. Dramat śledczy Porumboiu zrywa $\mathrm{z}$ kliszami gatunkowymi typowymi dla kina policyjnego[22]: pomija choćby scenę aresztowania młodocianych podejrzanych, zastępując ją służbowym (i moralnym) pojedynkiem między Cristi a jego przełożonym, Angelachem - nakręconym również w stylu tableau. Porażkę Cristiego, próbującego ochronić uczniów przed oskarżeniem i aresztowaniem, potwierdza w finale filmu rozrysowywany przez niego plan zatrzymania nastolatków na terenie szkoły (w którym ponownie architektura przestrzenna odgrywa pierwszorzędną rolę - szkolne podwórko idealnie nadaje się do odcięcia młodzieży jakiejkolwiek drogi ucieczki). Nie wiadomo jednak, jaki będzie efekt działań policji ani jakie konsekwencje dotkną Victora, Alexa i Doinę. Zasadniczą część akcji wypełniają bowiem działania operacyjne podejmowane przez Cristiego: żmudna obserwacja osób i budynków, pisanie raportów, próby uzyskania pomocy od kolegów w pracy. To pierwszy, eksplicytny poziom, na którym film Porumboiu jest dramatem śledczym.

Drugi, niedosłowny, wiąże się z historycznymi skojarzeniami uruchamianymi przez ten obraz. Pomimo bowiem iż Cristi stara się pomóc podejrzanym nastolatkom, jego przełożeni, kierujący aparatem policyjnym, sprawiają, że ostatecznie - także na skutek własnego konformizmu - zmuszony jest zaplanować zasadzkę na terenie szkoły. Wcześniej zaś składa raporty z prowadzonych działań w formie odręcznych notatek, szczegółowo opisujących kolejne, mało istotne obserwacje. Batori zwraca uwagę, że chociaż funkcjonariusz ma do dyspozycji komputer i wygodniejsze narzędzia cyfrowe, posługuje się odręcznie pisanymi notatkami i plikami dokumentów, co wprost „przywodzi na myśl niesławny aparat produkowania akt [w czasach] poprzedniego

[19] Á. Pethő, op.cit., s. 77.

[20] Por. I. Uricaru, op.cit.
[21] A. Batori, op.cit., s. 125.

[22] Ibidem. Por. także A. Virginás, op.cit., s. 190-191. 
reżimu"[23]. Co więcej, praca kamery w scenach inwigilacji sugeruje, że także sam Cristi jest obserwowany - subiektywny punkt widzenia, który początkowo skłonni jesteśmy utożsamić z bohaterem, okazuje się bowiem nie należeć do niego[24]. Tę wszechwiedzącą i kontrolującą perspektywę wirtualnie przypisać można Angelachowi, szefowi miejscowej policji, który ,jest figurą analogiczną do socjalistycznego Securiști - metaforą wszechmocnej i wszechpotężnej władzy, która przyczynia się do ustanowienia restrykcyjnego terroru i wykreowania uległych podmiotów i posłusznych obywateli”[25]. Tym samym na poziomie narzucających się wizualnych i fabularnych skojarzeń Policjant, przymiotnik przypomina o działalności Securitate, służb specjalnych inwigilujących i prześladujących obywateli w czasach rządów rumuńskiej partii komunistycznej. Wszystkie opisane elementy estetyczno-narracyjne filmu - od aury pogodowej poczynając, przez filmowaną w nim architekturę i scenografię, na działaniach bohaterów kończąc sprawiają, że świat przedstawiony w obrazie Porumboiu sprawia nieodparte wrażenie zanurzenia $\mathrm{w}$ dawnym komunistycznym systemie; jak określa to Anna Batori - „jest jego echem”[26].

Między opisywanymi filmami, przywołującymi na rozmaite sposoby komunistyczną przeszłość, istnieje szereg podobieństw, ale i różnic. W stosunku do dzieła Mungiu w obrazie Porumboiu wyczuwalny jest większy dystans - nie tylko czasowy, ale i emocjonalny: panoptyczna kamera w reprezentowanym przez niego wariancie częściej dystansuje się od bohaterów (w rozumieniu dosłownym), a przez to niejako skazuje widza na mniej zaangażowany odbiór. Jednak, jeśli wziąć pod uwagę konstrukcję przestrzeni filmowej oraz pełnione przez nią funkcje, podobieństwa są łatwo dostrzegalne. W obu przypadkach zarówno przestrzeń publiczna, jak i prywatna ze względu na swoje ukształtowanie łatwo stają się miejscem stałej, panoptycznej z ducha, obserwacji, w której ujawnia się i koncentruje opresyjność rzeczywistości oraz znajduje swe potwierdzenie zły stan relacji międzyludzkich. Panoptyczne spojrzenie w kinie rumuńskiej nowej fali przypisać można także samej kamerze, która podkreśla i wzmacnia odczucie stałego obserwowania, zamknięcia bohaterów w „dusznej” rzeczywistości (panoptycyzm nieustannych delikatnych ruchów). Socjalistyczna architektura ukazywana w świecie przedstawionym tych filmów blokuje możliwość łatwej społecznej interakcji i komunikacji - to architektura często dysfunkcjonalna i alienująca jednostkę. Do wszystkich świadczących o tym technik operatorskich i zabiegów inscenizacyjnych dodać można jeszcze jeden sposób wizualnego odseparowania postaci: wertykalne oddzielenie. Przybiera ono w analizowanych filmach postać dużej bariery oddzielającej bohaterów od siebie, filmowanej w taki sposób, że zajmuje ona znaczną część kadru. Postać wertykalnego oddzielenia przyjmują na przykład sceny z udziałem Otilii w hotelowych recepcjach

[23] A. Batori, op.cit., s. 131. [24] Ibidem.
[25] Ibidem.

[26] Ibidem. 
w 4 miesiącach... oraz rozmowa Cristiego z przełożonym w filmie Policjant, przymiotnik: podobieństwo między nimi jest wręcz zaskakujące. W obu przypadkach kamera została ustawiona tak, że na pierwszym planie znajdują się elementy scenograficzne - odpowiednio długa marmurowa lada i zagracone biurko. Wypełniają one niemal całą szerokość podstawy kadru. Mungiu dwukrotnie filmuje Otilię w sytuacji petentki w hotelu; obie rozmowy są kadrowane identycznie, zmienia się tylko strona, po której znajduje się kamera względem bohaterki.

W zasadzie wszystkie wiążące się z technikami operatorskimi i kreowaniem przestrzeni w filmowej mise-en-scéne cechy filmów Mungiu i Porumboiu odnaleźć można także w dziełach Cristiego Puiu. Panoptycyzm nieustannie poruszanej i obserwującej kamery, ujęcia w stylu tableau, wertykalne i horyzontalne domknięcie kadrów, wreszcie sam widok socjalistycznej architektury oraz pochodzących z tamtego okresu przedmiotów - wszystko to pojawiło się u Puiu już w Śmierci pana Lăzărescu. Film ten jest luźno oparty na historii mężczyzny, który zmarł na bukareszteńskiej ulicy 23 kwietnia 1997 roku[27]. Constantin Nica, pięćdziesięciodwuletni bezdomny, był, jak się okazało, odsyłany kolejno z czterech szpitali ze względu na spożycie alkoholu i - ogólnie rzecz ujmując - swoją podrzędną sytuację społeczną. Filmowa opowieść o gehennie Dante Remusa Lăzărescu - podobnie jak policyjny film Porumboiu - celowo zaciera granice między socjalistyczną przeszłością a kapitalistyczną teraźniejszością[28]. Zanim narzekającemu na ból brzucha bohaterowi uda się wreszcie wezwać pomoc medyczną i zostanie przetransportowany do pierwszego szpitala, akcja filmu rozgrywa się w jego mieszkaniu. U samotnego, żyjącego jedynie w towarzystwie trzech kotów, emerytowanego inżyniera panuje wyraźny bałagan, a wrażenie nieporządku wzmaga nagromadzenie przedmiotów z minionej epoki. Wśród wielu „znaków i symboli przeszłości”[29] znaleźć można także tak egzotyczny element wystroju, jak plakat Kim Wilde, światowej gwiazdy muzyki pop lat osiemdziesiątych. Mężczyzna wydaje się uwięziony we własnym mieszkaniu nie tylko przez problemy ze zdrowiem i z wezwaniem pomocy, ale także ze względu na przytłoczenie zmurszałymi przedmiotami. Przewiny i nadużycia dawnego reżimu powracają we współczesnym kontekście w formie hierarchicznych, dysfunkcyjnych i w gruncie rzeczy opresyjnych oddziałów szpitalnych, do których trafia Lăzărescu, bezskutecznie licząc na pomoc. Mimo podobnej estetyki, praca kamery $\mathrm{w}$ tym filmie prezentuje nieco inny wariant aniżeli w opisywanych wcześniej obrazach. Puiu nie operuje w tym filmie długimi ujęciami, a oprócz tego panoptyczna kamera Olega Mutu jest dużo bardziej mobilna - i labilna. Nie respektuje ona zasady 180 stopni, sytuując się w centrum diegetycznej przestrzeni i poruszając

[27] M. Filimon, Cristi Puiu, Urbana, Chicago, Springfield 2017, s. 60.

\section{Mieszkalnictwo i ideologia}


się nieraz wzdłuż trajektorii pełnych 360 stopni[30]. Nie zmienia to jednak faktu, że konsekwentny, „obserwujący” sposób realizacji zdjęć sugeruje istnienie wszechwi(e)dzącego spojrzenia, które wobec piętnowanych dysfunkcji systemu opieki zdrowotnej nabiera historycznych kontekstów i politycznego znaczenia.

Pełnometrażowy debiut Cristiego Puiu skłania do przyjrzenia się innemu jeszcze wymiarowi funkcjonowania przestrzeni w filmach rumuńskiej nowej fali - mianowicie warunkom mieszkalnym, w których zmuszeni są żyć bohaterowie. Tu także dziedzictwo historyczne kraju i całego regionu odgrywa zasadniczą rolę, gdyż na kolejne dziesięciolecia zadecydowało o kształcie rumuńskiej urbanistyki. W państwach socjalistycznych w okresie zimnej wojny szczególnego i strategicznego znaczenia nabrało przekształcenie miast zgodnie $\mathrm{z}$ obowiązującą doktryną społeczną, gospodarczą i polityczną. Miasta jako centra polityczne miały odzwierciedlać, oczywiście w sposób zaprojektowany przez władzę, potrzeby i plany socjalistycznej ludności (i w tym sensie stawały się także przestrzenią reprezentacyjną); były jednocześnie „wysiłkiem i produktem socjalizmu, determinującym wizualny charakter socjalistycznej przestrzeni społecznej"[31]. Najważniejszą część socjalistycznego projektu urbanistycznego w Europie Środkowej i Wschodniej stanowiły bloki mieszkalne, formowane zwykle w całe osiedla, projektowane i wznoszone przez powołane specjalnie w tym celu państwowe podmioty. Budynki te do dzisiaj stanowią dominujący krajobraz architektoniczny w krajach byłego bloku wschodniego i przypominają o ich niedawnej politycznej przeszłości.

Przypadek Rumunii wydaje się pod tym względem szczególnie ciekawy, jako że mowa o jednym z najbardziej nieprzejednanych reżimów komunistycznych, zarządzanym twardą ręką przez niemal ćwierć wieku przez jednego przywódcę, Nicolae Ceaușescu, którego projekty architektonicznego przekształcania przestrzeni społecznej były szeroko zakrojone. Anna Batori przywołuje dane, według których:

[...] ze względu na przymusową industrializację w Rumunii między rokiem 1948 a 1989 odsetek [mieszkańców] miejskich osiedli wzrósł z 23,4\% do $53 \%$. Doprowadziło to do ogromnego wzrostu „blokowiskowych dżungli” w miastach. [...] podczas gdy w 1966 roku tylko 17,4\% miejskiej populacji mieszkało w blokach mieszkalnych, do 1977 liczba ta przekroczyła $42 \%$, by wzrosnąć do $71,4 \%$ na początku lat $90[32]$.

Z przytoczonych informacji wynika zatem, że w ciągu czterech dekad po II wojnie światowej 30\% ludności Rumunii przeniosło się $\mathrm{z}$ rejonów wiejskich do miast, $\mathrm{w}$ strukturze których $\mathrm{z}$ każdym rokiem coraz większy udział miały bloki mieszkalne. W biografii rumuńskiego dyktatora pióra Thomas Kunze wielokrotnie powraca temat przekształcania rumuńskich miast i wsi w czasie jego rządów. Ceaușescu krótko po objęciu władzy zaczął wdrażać plan rozwoju mieszkalnictwa, do tego 
stopnia szeroko zakrojony, że w pewnych okresach na budowach pracowało wojsko[33]. Jak podaje Kunze, „tylko w latach 1981-1985 oddano do użytku 750 tysięcy nowych mieszkań" [34]. Projekty architektoniczne dyktatora, wznoszone wielkim społecznym wysiłkiem, podporządkowane były celom ideologicznym, czego najlepszym przykładem jest oczywiście słynny - nieukończony za życia pomysłodawcy - Dom Ludu (Casa Poporului) w Bukareszcie. „Zmysł estetyczny Nicolae Ceaușescu pisze Kunze - ukształtował stalinizm. Znał wyłącznie monumentalną architekturę, ogromne place okolone pompatycznymi stalinowskimi budowlami i bloki z wielkiej płyty"[35]. Do licznych grzechów Conducătora i jego żony Eleny zaliczyć trzeba niszczenie setek budynków, w tym historycznych i sakralnych, oraz przymusowe przesiedlanie ludności. W samym Bukareszcie proces ten nasilił się po trzęsieniu ziemi z 1977 roku. Później, w czasie budowy Domu Ludu, „zrównano z ziemią bukareszteńskie dzielnice Uranus, Antim i Rahova. Buldożery zmiażdżyły setki niewielkich, typowych dla okolicy domków"[36]. Przykładów gigantomanii przywódcy oraz jego obsesji na punkcie podyktowanego ideologią kształtowania przestrzeni życiowej Rumunów można by podać bardzo wiele. To między innymi one doprowadziły ostatecznie do niewypłacalności kraju i skrajnego zubożenia ludności oraz pogorszenia się warunków życia w latach osiemdziesiątych. By zobrazować skalę represji i niewydolności państwa, wystarczy wspomnieć o blokowaniu dostaw energii do mieszkań:

Na porządku dziennym były przerwy w dostawie prądu i gazu. Poza paroma wyjątkami w Bukareszcie nie włączano na noc oświetlenia ulic. Od 1986 roku temperatura $\mathrm{w}$ bukareszteńskich blokach z wielkiej płyty nie mogła przekraczać zimą 12 stopni Celsjusza. Cały naród chodził spać w czapkach i płaszczach[37].

Bloki wznoszone przez socjalistyczne państwo na wiele różnych sposobów uwikłane były w nierówne stosunki władzy i projekt politycznego podporządkowania obywateli[38]. Po pierwsze, już samo wprowadzenie się do lokalu mieszkalnego (własnościowego lub nie) nie było wyborem leżącym w gestii zainteresowanych osób, ale zależało od decyzji partyjnych urzędników (i zależało od szeregu czynników, takich jak pochodzenie czy stosunek do partii). Po drugie, budownictwo to często złożone z ciasnych mieszkań, z pomieszczeniami o niewystarczająco dużej powierzchni - zmierzało do ograniczenia przestrzeni prywatnej mieszkańców [39]. Jak przekonują filmy omawianego nurtu, architektura mieszkaniowa - obszernie fotografowana w tym kinie - ze

[33] T. Kunze, Ceaușescu. Piekło na ziemi, przeł.

J. Czudec, Warszawa 2016, s. 217.

[34] Ibidem, s. 318.

[35] Ibidem, s. 323.

[36] Ibidem, s. 324 .

[37] Ibidem, s. 327.

[38] A. Batori, op.cit., s. 25-26.
[39] Ibidem, s. 22-26. Powołując się na badania Henriego Lefebvre’a, badaczka zauważa przy tym, że kapitalizm w podobny sposób, choć z innych pobudek, wydziela jednostkom przestrzeń mieszkalną i jest zainteresowany podporządkowaniem ich na rzecz kapitalistycznego miasta. 
względu na swoje zaprojektowanie przestrzenne i ciasnotę skazuje bohaterów na ciągły brak intymności - na nadmierną bliskość obcowania z innymi domownikami, która okazuje się szczególnie trudna w momentach konfliktów i kryzysów. Po trzecie wreszcie, stłoczenie dużej liczby mieszkańców pod jednym dachem i na niewielkiej przestrzeni ułatwiało ich inwigilację. Pozbawienie prywatności oraz narażenie na stałą obserwację - choćby i sąsiedzką - to sprawdzone mechanizmy dyscyplinujące[40], które socjalistyczne władze wykorzystywały w celu nadzorowania własnych społeczeństw. Wszystkie te kwestie znajdują swe odbicie w Śmierci pana Lăzărescu.

Puiu w początkowych scenach filmu wprowadza dwie ważne, powracające także $\mathrm{w}$ innych filmach rumuńskiej nowej fali, przestrzenie: kuchnię i klatkę schodową. Jak zauważa Deaca, zainscenizowane w kuchni sceny - ze względu na kulturowe nacechowanie tej przestrzeni, budzącej skojarzenia z intymnością i wspólnymi posiłkami - niosą zwykle ważne symboliczne przesłanie, a także odsłaniają prawdziwą twarz bohaterów. „Sceny wokół stołu są prototypowe w ocenie wartości, które spajają wielopokoleniowy rodzinny krąg i determinują, czy [przybyły] gość [...] jest akceptowany - czy nie"[41]. Lăzărescu przy stole jest zupełnie sam - jego jedyna córka mieszka w Kanadzie; do nędznego posiłku pije więc Mastropol, domowej roboty alkohol z dodatkiem karmelu i wanilii, który wydaje się środkiem służącym do zaleczenia wewnętrznego bólu. Jak ujmuje to Mircea Deaca, „kuchnia jest przedsionkiem śmiertelnej podróży bohatera, który od samego początku jest chodzącym trupem, skrępowanym $\mathrm{z}$ góry ustalonym losem" [42]. Gdy bohater dzwoni po pomoc, siedząc przy kuchennym, zabrudzonym stole, widzowie mają szansę przyjrzeć się dokładnie jego otoczeniu, z piecykiem gazowym przypominającym o braku dostaw ogrzewania, na czele.

Sceny przy stole pojawiają się także w wielu innych filmach rumuńskiej nowej fali. Oprócz wspomnianej już wizyty Otilii u rodziców Adiego, podczas której znajdująca się w centrum kadru dziewczyna doznaje upokorzenia od pozostałych biesiadników, przez co odmawia jedzenia i niechętnie godzi się na toast, w zakończeniu niespodziewanie obie bohaterki spotkają się w hotelowej restauracji. Găbitą, która poczuła się lepiej, schodzi na dół i otrzymuje jedyny dostępny posiłek, składający się z samych mięsnych podrobów. Powrót do „normalności” po przeprowadzonej aborcji wydaje się aż nazbyt nagły; Mungiu niespodziewanie przekłuwa narastającą od dłuższego czasu atmosferę niepewności i zagrożenia, która znajduje kulminację, gdy Otilia nie zastaje swej koleżanki w pokoju. Widzowie spodziewający się dramatycznego zakończenia skonfrontowani zostają ze sceną (pozornego przecież) uspokojenia i wyciszenia. Bezpośredni zwrot w ich kierunku

[40] Por. M. Foucault, Nadzorować i karać. Narodziny więzienia, przeł. T. Komendant, Warszawa 1998.
[41] M. Deaca, Kitchen encounters: scenes of face-to-face dialogue in films of the new Romanian cinema, [w:] The New Romanian Cinema..., s. 198.

[42] Ibidem, s. 202. 
jest wyraźny w finale filmu - w ostatnim ujęciu grająca Otilię aktorka, Anamaria Marinca, odwraca głowę i kieruje wymowne, zbolałe spojrzenie wprost do kamery. Mungiu kończy w tym momencie swój film.

Warto w tym miejscu przeanalizować także sceny powrotów do

domu Cristiego w filmie Policjant, przymiotnik. Bohater filmu trzykrotnie sam lub w towarzystwie żony spożywa posiłki. Porumboiu każdorazowo wykorzystuje te fragmenty, by podkreślić ciasnotę ich mieszkania, ale także - nieco paradoksalnie - emocjonalne oddalenie i brak porozumienia. W pierwszym wariancie mężczyzna jest $\mathrm{w}$ domu sam i, nie wstając od stołu, odgrzewa obiad na kuchence gazowej - wystarcza mu do tego tylko półobrót na kuchennym stołku. Innym razem Cristi je w kuchni kolację, tym razem siedząc po drugiej stronie stołu, i w identyczny sposób otwiera lodówkę, podczas gdy Anca w pokoju obok odtwarza ciągle tę samą piosenkę (Nu te părăsesc iubire Mirabeli Dauer) - której mimowolnie musi słuchać także Cristi, choć wyraźnie nie ma na to ochoty[43]. Dalszy ciąg tej sceny, filmowanej w jednym długim ujęciu z korytarza mieszkania, obejmować będzie dyskusję słabo wykształconego policjanta $\mathrm{z}$ będącą nauczycielką żoną na temat tekstu piosenki - metaforycznego znaczenia zawartych w nim obrazów i symboli. Istotne jest to, że wykorzystując architekturę ciasnego, socjalistycznego mieszkania, Porumboiu nie tylko kreśli współczesny portret młodego małżeństwa i przeżywanych przez niego trudności, ale także kieruje uwagę widzów na same warunki przestrzenne wpływające na relacje bohaterów. Ostatni posiłek oglądany w filmie, tym razem już wspólny, nie przynosi przełomu. Żona Cristiego - jak zauważa cytowana autorka - „nie służy mu radą ani moralnym wsparciem, którego on tak bardzo potrzebuje, ale pozostaje pasywnym świadkiem jego duchowej agonii" [44]. Anca ponownie poucza swojego męża - tym razem wytyka mu błąd rodzajnika w służbowej notatce.

W Śmierci pana Lăzărescu tytułowy bohater, wobec niemożności wezwania pomocy medycznej, szuka ratunku u sąsiadów. Rozgrywająca się początkowo na klatce schodowej scena jest jedną z tych, która wprowadza do filmu elementy komiczne przez gasnące co rusz światło oraz zachowania mieszkającego naprzeciwko małżeństwa, próbującego niby pomóc Lăzărescu, a w istocie wypominającego mu pijaństwo oraz zajętego własnymi sporami. Puiu filmuje całą trójkę z dystansu, oczywiście przy wykorzystaniu chybotliwej kamery z ręki, początkowo nie przekraczając progu mieszkania Lăzărescu, co uwypukla pozorną sąsiedzką bliskość, a w istocie gruntowną nieufność, i pozwala wprowadzić humor sytuacyjny. Jak udowadniają polskie oraz czechosłowackie filmy i seriale wyprodukowane w czasach republik ludowych, blokowiska i wiążące się z nimi bliskie sąsiedztwo mogą stanowić dobre miejsce akcji dla utworów komediowych piętnujących absurdy socjalizmu. Przykładem tego rodzaju, pochodzącym z nowego kina rumuńskiego, są nowelo-

[43] Więcej na temat znaczenia dialogu i muzyki w tej scenie - zob. I. Uricaru, op.cit., s. 56-58.

[44] M. Deaca, op.cit., s. 205. 
we Opowieści złotego wieku (Amintiri din epoca de aur, 2009). Warto zauważyć, że funkcję filmowej czołówki, łączącej poszczególne części obrazu, pełni tu animacja oparta właśnie na motywie klatki schodowej. Film ten w gorzki i burleskowy sposób portretuje rumuńską rzeczywistość w czasach późnych rządów Ceaușescu. Jednakże w komediodramacie Puiu samotny bohater zostaje dodatkowo pognębiony przez swoich wścibskich sąsiadów, którym jednak nie można odmówić chęci pomocy. Klatka schodowa jako specyficzna, półprywatna przestrzeń przywodzić może zatem dwojakie skojarzenia - oprócz familiarności i ofiarności wprowadza także reminiscencje stałego obserwowania i wzajemnej kontroli mieszkańców. Wszak instytucja osiedlowego administratora (informatora) w komunistycznej Rumunii była doskonale rozpoznawalna.

Zabrany wreszcie ze swego mieszkania, cierpiący bohater trafia $\mathrm{z}$ jednego oddziału ratunkowego na drugi. Zderza się w ten sposób $z$ bezdusznym opresyjnym aparatem państwowym, którego emanacją jest służba zdrowia. Jak pisze Monica Filimon, właśnie odarcie mężczyzny z godności wydaje się największą krzywdą, jaka go spotyka, zwłaszcza że wyrządzają ją osoby powołane do niesienia pomocy[45]. Jedynie sanitariuszka Mioara - również strofowana przez lekarzy, znajdująca się na dole hierarchii systemu opieki zdrowotnej - empatyzuje z Lăzărescu. Filimon nazywa ją nawet alter ego protagonisty, jako że, podobnie jak on, cierpi na chroniczny ból (łagodzony środkami przeciwbólowymi) oraz jest matką zawiedzioną postawą swego syna (i - szerzej - całego młodego pokolenia)[46]. Mimo tych podobieństw, których bohaterowie raczej sobie nie uświadamiają, Mioara pogarsza sytuację chorego, na własną rękę stawiając diagnozy i w konsekwencji podejmując niewłaściwe decyzje medyczne. Tracącego przytomność bohatera lekarze zaczynają leczyć zbyt późno - tytuł sugeruje to widzowi od samego początku, chociaż samej śmierci nie zobaczymy na ekranie. Puiu skupia się na ukazaniu licznych granic (także czysto wizualnych, w postaci linii, kotar czy fizycznych przeszkód), których nie może przekroczyć - ani o własnych siłach, ani przy asyście ratowników medycznych - umierający pacjent.

Przestrzenie symboliczne (prolegomena)
Późniejszy film Cristiego Puiu, Sieranevada (2016), również wykorzystuje niewielką przestrzeń mieszkania, tym razem by zobrazować zakorzeniony $\mathrm{w}$ prawosławnych wierzeniach rytuał ostatniego pożegnania zmarłego czterdzieści dni po jego śmierci. Spotkanie licznie zgromadzonej rodziny Emila filmowane jest w typowy dla nowej fali kina rumuńskiego sposób: za pomocą długich ujęć, przy użyciu mobilnej kamery i w ramach ograniczonej czasoprzestrzeni. W centrum zainteresowania Puiu w Sieranevadzie znalazła się kwestia postępującej sekularyzacji i dezintegracji rumuńskiego społeczeństwa. Upamiętnienie zmarłego, będące powodem rodzinnego spotkania, schodzi na 
dalszy plan pod naporem licznych sporów i przyziemnych rozmów. Jak słusznie zauważa Monica Filimon, śledząca zachowanie bohaterów kamera tym razem wydaje się uosabiać spojrzenie i obecność zmarłego[47]; w tym sensie jest to oczywiście zabieg podkreślający rozziew między „spirytualną” treścią rytuału, a sposobem, w jaki przeżywa go większość rodziny. Sieranevada udowadnia zresztą, że w twórczości Cristiego Puiu znaleźć można powracające stale toposy związane ze śmiertelnością - zwłaszcza to, jak cielesna bliskość śmierci nie pozwala na pokonanie psychologicznego dystansu względem niej[48]. Problematyka społeczna i polityczna - także ta dotycząca bilansu i rozliczenia czasów komunizmu - pojawia się w filmie, jednak tym razem na plan pierwszy wysuwają się kwestie związane z religijnością i duchowością. Pozostając wiernym poetyce realizmu, reżyser poddaje oględzinom miejsce i siłę oddziaływania rytuału w realiach szybko modernizującej się, współczesnej Rumunii. Kamil Kalbarczyk pisał w recenzji filmu na łamach „Ekranów”:

Sieranevada to obraz trzech pokoleń, z których najstarsze pamięta jeszcze czasy rządów Gheorghiu-Deja, środkowe - wychowane podczas dyktatury Ceaușescu - stoi w rozkroku między dawnym a obecnym ustrojem, zaś najmłodsze to dzieci i nastolatki: beneficjenci integracji europejskiej, nieznający piętna politycznych opresji i narodowych kompleksów. [...] Panichida, będąca powodem spotkania całej rodziny, jest w istocie reliktem przeszłości, wydarzeniem doniosłym już tylko dla pokolenia dziadków - strażników wiary i tradycji. Ich dzieci podchodzą do tego nieco lekceważąco, zaś najmłodsza latorośl dostrzega w tym rytuale głównie żartobliwy potencjał[49].

Sądzę jednak, że ostatecznie Sieranevadę odczytywać należy w kluczu postsekularnym, w którym „rytualne gesty - jak pisze Magdalena Mączyńska - zarówno werbalne jak i niewerbalne, nie są ani całkowicie świeckie, ani całkiem sakralne; nie są ani kanałami transcendencji łączącymi wierzącego ze stanem ontologicznej pełni, ani szczątkami minionej epoki unoszącymi się w duchowej pustce bezbożnej nowoczesności" [50]. Akcja filmu zbyt mocno koncentruje się na rytuale, by uznać go za jedynie pretekstowy. Na przenikanie się sfery rodzinnej i rytualnej w Sieranevadzie zwraca uwagę Andrzej Szpulak, który zauważa, że uczestnictwo w zbiorowym uczczeniu zmarłego przodka zyskuje dzięki temu znaczenie szersze - jest sposobem na przyjęcie i przyswojenie własnego kulturowego dziedzictwa[51]. Przedstawiciele młodego pokolenia, mimo wahań i oporów, ostatecznie dołączają do

[47] Ibidem, s. 116.

[48] Filimon pisze o nich w kontekście filmu Śmierć pana Lăzărescu. Ibidem, s. 60.

[49] K. Kalbarczyk, Tango z tradycja, „Ekrany” 2017, nr 1 (35), s. 39.

[50] M. Mączyńska, Toward a postsecular literary criticism. Examining ritual gestures in Zadie Smith's „Autograph Man”, „Religion and Literature” 2009, no.
41; cyt. za: K. Jarzyńska, Postsekularyzm - wyzwanie dla teorii i historii literatury (rozpoznania wstepne), „Teksty Drugie” 2012, nr 1-2 (133-134), s. 301. [51] A. Szpulak, Z duchami przodków wzdłuż południka. Filmowo-literacka „Via Carpathia”, <nowynapis.eu/tygodnik/nr-26/artykul/z-duchami-przodkow-wzdluz-poludnika-filmowo-literacka-carpathia> [dostęp: 4.04.2020]. 
rodzinnej gromady (jak czyni wnuczka Emila w momencie przybycia duchownego) i dopełniają rytuału, godząc się nawet na trudne dla nich gesty (jak założenie garnituru zmarłego).

Jeśli dziewczyna - pisze autor - która wygląda na typową dla jej pokolenia, dwudziestoletnią bon vivantkę, a która dodatkowo przyprowadza na uroczystość nieprzytomną z powodu spożycia nadmiaru alkoholu lub narkotyków koleżankę, wbrew wyraźnemu zakazowi ciotki opuszcza zamknięty pokój, by przez chwilę pozostać w rytualnej bliskości ze swą rodziną, jeśli młody mężczyzna niechętnie, ale przyjmuje strój zmarłego antenata, to $\mathrm{w}$ jakiśs, bardzo niedoskonały, sposób łączą się oni z czymś większym od siebie, przestrzenią o szerszym, niewyłącznie teraźniejszym horyzoncie[52].

W tym miejscu chciałbym zauważyć, że obok kluczowej dla rumuńskiej nowej fali tematyki związanej z komunizmem i transformacją polityczną po 1989 roku najwybitniejsze dzieła tego nurtu cechuje także możliwość odczytania na płaszczyźnie etycznej, symbolicznej czy wręcz religijnej. Jak zaświadczają analizy Doru Popa, Monicy Filimon czy Mircei Deacy, filmy takie, jak właśnie 4 miesiące, 3 tygodnie i 2 dni, Śmierć pana Lăzărescu, Policjant, przymiotnik, 12:08 na wschód od Bukaresztu czy Aurora (reż. Cristi Puiu, 2010) mają wiele symbolicznych znaczeń, ukrytych w licznych podtekstach i ikonograficznych aluzjach. Ikonologiczne analizy Doru Popa, czerpiące wzorce i inspirację z prawosławia, przekonują, że w dziełach tych obecne są nieoczywiste sensy moralne i religijne, choć przyjmują one zwykle formę postsekularnej negatywności, a przynajmniej paradoksalności[53]. Dla przykładu: postać Otilii w filmie Mungiu, mimo współudziału w zabiegu aborcji, jednocześnie bezinteresownie poświęca się dla swojej przyjaciółki. Nie jest jednak posłańcem życia, a śmierci („kimś w rodzaju Madonny z martwym płodem, jak «zdegradowane» obrazy Matki Boskiej we współczesnej sztuce" [54]), o czym w alegoryczny sposób świadczą też - zdaniem badacza - sceny posiłków obecne w filmie, dla których punkt odniesienia stanowić ma Ostatnia Wieczerza, przetransponowana w filmowym świecie tak, że pozbawia go wymiaru sakralnego. Tego rodzaju analizy można uzupełnić o podobne argumenty płynące $\mathrm{z}$ samych zdjęć autorstwa Olega Mutu. Gdy Otilia wyrzuca martwy płód do zsypu na śmieci, zgodnie z zaleceniami Bebe (a wbrew woli Găbity, która prosiła, by go pogrzebać), trzykrotnie - literalnie - wstępuje w ciemność: podążająca za nią kamera, pozbawiona źródła światła, zanurza się w mroku.

Finałowa scena konfrontacji Cristiego z upokarzającym go Angelachem (notabene, w roli tej występuje Vlad Ivanov, który wcześniej wcielił się w czarny charakter - lekarza Bebe - w obrazie Mungiu) w filmie Policjant, przymiotnik siłę czerpie z konsekwencji, jakiej wymaga sfilmowanie długiej rozmowy między trzema prawie nieruchomymi bohaterami $\mathrm{w}$ jednym frontalnym ujęciu. $\mathrm{W}$ tym przypadku jednak

[52] Ibidem.

[54] Ibidem, s. 145.

[53] Zob. D. Pop, Romanian New Wave Cinema...,

s. $140-152$. 
filmowe tableau wywołuje inne jeszcze skojarzenia. Rozmieszczenie mężczyzn w obrębie kadru oraz stojący pośrodku nich stolik z naczyniem $\mathrm{z}$ owocami sugerują, że ikonologicznego wzorca dla tego kadru dostarcza ikona Trójcy Świętej Andrieja Rublowa[55]. Oczywiście, wzorzec ten ponownie poddany jest daleko idącej dekonstrukcji. Należy podkreślić, że symbolika używana przez Mungiu, Porumboiu i innych reżyserów kina rumuńskiego jest mimo wszystko nienachalna, co ma oczywiście silny związek z minimalistyczną estetyką tego kina. Duchowa pustka, brak nadziei i zanik moralności, o których opowiadają te filmy, konstruowane są jednakowoż często z wykorzystaniem religijnego horyzontu odniesienia i przez odwołania do chrześcijańskiej ikonografii.

Na etyczną stronę filmów rumuńskiej nowej fali zwracał z kolei uwagę na łamach „Images” Rafał Syska, pisząc:

W szystkie najwybitniejsze rumuńskie filmy [...] polskiemu widzowi muszą przypominać osiągnięcia kina moralnego niepokoju. W obu wypadkach polityka [...] ustępuje miejsca dysputom etycznym, rozważaniom o moralnych konsekwencjach czynów (a często bezczynności), o nieufności i rozpadzie społecznych relacji, a także dyktacie pragmatyzmu, który prowadzi do oportunizmu i służalczości. Żaden rumuński film nie pozostawia widzów w optymizmie: system (zarówno ten komunistyczny, jak i ten, który okazał się postkomunistyczny) uzbroił ludzi w narzędzia konformizmu i egocentryzmu. Poczucie wspólnoty nie wykształciło się z powodu kompromitacji mitów założycielskich nowego państwa i daremności rewolucyjnych ofiar, a fałsz stał się kodem w komunikacji między ludźmi[56].

Moje rozważania koncentrowały się na obrazowaniu w latach 2005-2010 w kinie rumuńskim totalitarnej przeszłości tego kraju. Jak starałem się wykazać, wyraziste modelowanie przestrzeni filmowej praktykowane $\mathrm{w}$ ramach minimalistycznej estetyki służyło twórcom za jeden z głównych sposobów przywoływania i negatywnego portretowania (post)komunistycznych realiów życia w Rumunii. Zjawisko to poddał krytyce Claudiu Turcuş, który twierdzi, że doszło wówczas w kinie rumuńskim do swoistej uniformizacji artystycznego, ale i ideowego ukształtowania dzieł filmowych[57]. Zdaniem badacza osiągnięcia rumuńskiej nowej fali nie tylko nie były innowacyjne pod względem obrazowym i narracyjnym, ale też okazały się podporządkowane jednej historycznej perspektywie. Punkt widzenia Turcuşa dobrze odzwierciedlają jego uwagi kierowane pod adresem obrazu 4 miesiace, 3 tygodnie i 2 dni. Badacz pisze, że w dziele tym „słowo «komunizm» nie jest wymawiane, ale jego stereotypami są nasycone niemal wszystkie ujęcia: Mungiu nie oparł się pokusie zobrazowania barbarzyństwa Wschodu" [58]. Badacz przywołuje w tym kontekście takie sceny, obrazy i cechy filmowego świata przedstawionego, jak: wszechobecna inwigilacja (w tym przypadku w hotelach), drobna codzienna korupcja,

[55] Ibidem, s. 150-151.

[56] R. Syska, op.cit., s. 13-14.
Przestrzeń między minimalizmem a melodramatem
[57] C. Turcuş, op.cit., s. 224-232.

[58] Ibidem, s. 230. 
ogólna degradacja społeczna (począwszy od budynków i warunków mieszkalnych po przemoc międzyludzką). Turcuş wspomina o zacofaniu, prowincjonalności i biedzie, a wreszcie także osobistej traumie bohaterek. Jego zdaniem każe to postawić pytania o zależność filmowej pamięci o komunizmie od horyzontu oczekiwań zachodniej publiczności[59]. Autor zastanawia się, czy tak jednolita wizja systemu (nie tylko w filmie Mungiu, ale i w wielu innych filmach rumuńskiej nowej fali) nie świadczy o swoistym wschodnioeuropejskim autoorientalizmie, w którym ukazywanie rumuńskiej przeszłości z zachodniej perspektywy (i przy wykorzystaniu wyrafinowanej estetyki, która daje szansę zauważenia i artystycznego docenienia w krajach kulturowego centrum) zdradza głęboko uwewnętrznione przeświadczenie o własnej podrzędności[60]. A przy tym, co istotne, przyjęcie tej właśnie perspektywy świadczyć ma o przezwyciężeniu komunistycznej przeszłości. Turcuş twierdzi ostatecznie, że na tak postawione pytania nie da się odpowiedzieć jednoznacznie, gdyż wartość artystyczna i zróżnicowane poetyki opisywanych przez niego filmów - oprócz 4 miesięcy... także Opowieści złotego wieku i 12:08 na wschód od Bukaresztu - na to nie pozwalają. W filmie Mungiu szczególnie ważna jest dla niego scena rozmowy między Otillią a Găbitą po wyjściu Bebe: fakt, że mimo właśnie doświadczonej przez nie traumy nie następuje intensyfikacja dramatycznych wydarzeń - „nie dzieje się nic melodramatycznego”[61]. Bohaterki starają się zracjonalizować to, co się wydarzyło, oraz powrócić do normalności - chociaż ceną za to ma być utrata pamięci (postanawiają nigdy więcej nie poruszać tematu wymuszonego na nich gwałtu). Intymność przeżyć bohaterek jest - zdaniem badacza - tym, co nie pozwala przypisać obrazowi Mungiu jednostronności historycznego obrazowania, wymyka się ona bowiem uciskowi totalitarnemu[62] oraz autoorientalnej logice skupiania się na traumatycznych aspektach przeszłości.

Chociaż sam Turcuş zawiesza część stawianych przez siebie zarzutów, to jego uwagi pod adresem zarówno politycznego, jak i estetycznego oblicza rumuńskiej nowej fali zmuszają do ostrożności i ponownego przemyślenia tego, co charakteryzowało najważniejsze filmy nurtu. Badacz sugeruje bowiem, że istnieje wyraźny kłopot z jednoznacznymi rozstrzygnięciami dotyczącymi kwestii fundamentalnych dla kina rumuńskiego po roku 2005. Jedną z nich jest dylemat, czy należy traktować je jako modelową artystyczną emanację pamięci postkolonialnej, czy też raczej jako neo- i autokolonialne zjawisko artystyczne, w nowej sytuacji geopolitycznej podporządkowane nowemu hegemonowi. Dla obu tych tez można znaleźć stosowne argumenty, choć większość (warto dodać: zachodniocentrycznie nastawionych) badaczy kładzie nacisk na wyzwolenie się Rumunii z kolonialnego sowieckiego ucisku. W tej perspektywie najważniejsza wydaje się - opisywana przez teoretyków

[59] Ibidem, s. 229.

[60] Ibidem.
[61] Ibidem, s. 231.

[62] Ibidem, s. 232. 
postkolonializmu - konieczność przypomnienia własnej bolesnej przeszłości, wraz z wypartymi i niechcianymi jej aspektami. Chodzi tutaj nie tylko o odsłonięcie kolonialnej przemocy, ale i własnego w niej uczestnictwa, a nawet współudziału[63]. W tym sensie nowe kino rumuńskie, uparcie - pośrednio lub bezpośrednio - powracające do czasów dyktatury Nicolae Ceaușescu oraz diagnozujące postsocjalistyczne społeczne bolączki, pełniłoby funkcję nie tylko „,historyczną”, ale i terapeutyczną, ostateczny osąd przeszłości i teraźniejszości pozostawiając widzowi.

Podobny kłopot z jednoznacznym opisaniem nowej fali kina rumuńskiego zauważam w strukturze przedstawieniowej filmów ją reprezentujących, w czym szczególną rolę - co zaraz wyjaśnię - odgrywa właśnie przestrzeń filmowa. Minimalizm stał się, rzadko w istocie problematyzowanym[64], wytrychem przesądzającym o odbiorze kolejnych filmów z tego kraju. Znaczącym dopełnieniem minimalistycznej estetyki kina rumuńskiej nowej fali miała być wspomniana przez Turcuşa ucieczka od melodramatyzmu. Iona Uricaru, komentując rezygnację z muzyki niediegetycznej i zawierzenie realizmowi przez rumuńskich twórców, stwierdza jednakowoż, że to nie one przesądzają o melodramatyczności dzieła filmowego. Czynnikiem tym jest, jej zdaniem, przyjęcie lub odrzucenie mitu fundującego melodramatyczną konwencję, czyli „wiary w istnienie dobra, które jest opozycyjne w stosunku do zła, uzupełnione przez umiejętność wyboru przez protagonistę tego dobra i działanie na jego rzecz” [65]. Zdaniem badaczki „najważniejsze teksty nowego kina rumuńskiego ujawniają fundamentalną, egzystencjalną nieufność co do samych przesłanek melodramatu - istnienia, zrozumiałości, dostępności i dynamicznej opozycji dobra i zła”[66]. Uricaru upatruje w tym doniosłego znaczenia opisywanego nurtu filmowego, w którym melodramatyczny, emocjonalny eksces i heroiczne wybory bohaterów zastępuje nieprzejrzysta, skomplikowana, czasem absurdalna rzeczywistość, pozbawiona punktów oparcia i niegwarantująca widzowi przyjemności empatyzowania z bohaterami. Minimalizm inscenizacyjny i przestrzeganie zasad filmowego realizmu, w tym rezygnacja $\mathrm{z}$ „emocjonalnego” wykorzystywania muzyki, mają razem jak konkluduje Uricaru - służyć w kinie rumuńskim takiej właśnie, niemelodramatycznej budowie światów przestawionych [67].

[63] Zob. np. L. Gandhi, Teoria postkolonialna. Wprowadzenie krytyczne, przekł. J. Serwański, Poznań 2008. Ciekawie współbrzmi z tą perspektywą to, co o polityce obłudy w komunistycznej Rumunii pisze Gail Kligman: „Społeczne mechanizmy funkcjonowania życia codziennego były konstruowane przez sam ustrój socjalistyczny i w istotny sposób przyczyniły się do przetrwania reżimu. Obłuda i współudział były mechanizmami hegemonicznymi, poprzez które organizowano relacje społeczne i poprzez które utrwalano społeczeństwo socjalistyczne, a w ostatecznym rezultacie je zniszczono". Idem, Polityka obłudy. Kontrola rozrodczości w Rumunii pod rządami Ceaușescu, przeł. P. Art, Kraków 2010, s. 28-29.

[64] Jedną z nielicznych udanych prób tego rodzaju jest artykuł Iriny Trocan z cytowanego często zbioru esejów The New Romanian Cinema. Por. eadem, Minimalism in the new Romanian cinema: Absent, omnipresent or misjudged?, [w:] The New Romanian Cinema..., s. 36-49.

[65] I. Uricaru, op.cit., s. 59.

[66] Ibidem.

[67] Ibidem, s. 62. 
Andrea Virginás zwraca jednak uwagę, że nawet dzieła filmowe utrzymane w minimalistycznej poetyce, zwłaszcza te ukazujące traumatyczne przeżycia bohaterów, wykazywać mogą pewne cechy melodramatyczne[68]. Virginás wykorzystuje spojrzenie na melodramat Thomasa Elsaessera, który w studium Opowieści wściekłości i wrzasku. Uwagi o rodzinnym melodramacie wskazywał, że konflikt w ograniczonym do wąskiego grona osób melodramacie często maskuje (czyli odzwierciedla, ale fałszując bądź podmieniając obraz) „rzeczywisty” kryzys społeczny bądź konflikt ideologiczny[69]. Oprócz tego Elsaesser wymienia cały szereg możliwych rozwiązań dramaturgicznych i cech charakterystycznych dla melodramatów rodzinnych - są wśród nich i takie, które dobrze opisują postkomunistyczne kino (nie tylko) rumuńskie. Wskazać wśród nich można choćby: koncentrację na punkcie widzenia ofiary, opowiadanie o niepowodzeniu niedostosowanego do otoczenia protagonisty, nabywanie wiedzy przez cierpienie, wykorzystanie formuły ironii lub patosu czy wreszcie usymbolicznienie znaczenia przestrzeni i dekoracji. Grażyna Stachówna, pisząc o ideologii i perswazji w melodramacie filmowym, przypomina, iż choć „powszechnie uważa się, że melodramat jest przeciwieństwem wszystkiego, co można uznać za realizm filmowy”[70], a „przeciwko melodramatowi przemawiały zawsze jego «ekscesy»"[71], to „tam [...], gdzie w grę wchodzą przeżycia emocjonalne i moralne, gdzie skłania się widzów do sympatii dla ofiar, gdzie opowiadanie angażuje się w odsłanianie psychologicznych przyczyn postępków i działań bohaterów, zawsze pojawia się melodramatyczność" [72]. Sądzę zatem, że rys melodramatyczny można dostrzec także w większości filmów rumuńskiej nowej fali, nawet pomimo ich realistycznej poetyki oraz cechującego je minimalizmu.

Warto zwrócić uwagę na przykład na te fragmenty filmów, w których niepostrzeżenie dochodzi do rezygnacji z chłodnego, obserwacyjnego stylu filmowania, a zamiast niego kamera pośredniczy w przekazaniu intymności przeżyć bohaterów. Taki moment pojawia się w 4 miesiącach..., gdy Otilia bierze na siebie nocą ciężar pozbycia się martwego płodu - kamera podąża za nią krok w krok, słyszymy jej ciężki oddech będący sygnałem przerażenia; bohaterka zostaje także dodatkowo wystraszona przez bezdomnego psa. Melodramatyczny eksces w tej scenie ma swój minimalistyczny odpowiednik: po wszystkich traumatycznych przeżyciach Otilia zatrzymuje się w zaułku ciemnej, spowitej mgłą ulicy i wymiotuje. Podobnie oczyszczającą funkcję pełnią też liczne sceny przemywania się w łazience. W filmie Mungiu fizjologicznych ekscesów jest zresztą dużo więcej, podobnie jak w Śmierci pana

[68] A. Virginás, Fragile diegetic spaces and mobile women: coping with trauma in Hungarian and Romanian films, [w:] Cultural Studies Approaches..., s. $66-84$.

[69] Melodramat amerykański w ujęciu badacza wiąże się nieodłącznie z ideologią burżuazyjną.

T. Elsaesser, Opowieści wściekłości i wrzasku. Uwagi o rodzinnym melodramacie, przeł. S. Bobowski, „Studia Filmoznawcze" 2008, nr 29, s. 11-39.

[70] G. Stachówna, Niedole miłowania. Ideologia i perswazja $w$ melodramatach filmowych, Kraków 2001, s. 23.

[71] Ibidem.

[72] Ibidem. 
Lăzărescu. W tym drugim filmie tytułowy bohater podlega w kolejnych szpitalach daleko idącemu uprzedmiotowieniu i odpodmiotowieniu (stopniowo traci kontrolę nad funkcjami życiowymi), ale jego agonia w dużej mierze zostaje zbagatelizowana. Odzwierciedlająca ten proces kamera nie skupia się przesadnie na cierpiącym Lăzărescu; moment większej intymności ustanowiony zostaje dopiero pod koniec filmu, gdy mężczyzna nie chce wyrazić zgody na neurologiczną operację, bojąc się możliwego paraliżu. Przygotowywanie nagiego pacjenta do zabiegu przez pielęgniarki wieńczy film obrazem skrajnie intymnym, a przy tym przesyconym fizyczną bezradnością i wyczerpaniem.

Andrea Virginás przekonuje, że milczenie oraz zakaz mówienia, będące typową odpowiedzią straumatyzowanych, zwłaszcza żeńskich, podmiotów na doznane krzywdy, w kinematografiach postsocjalistycznych znaczyć mogą zarówno zahamowaną społeczną mobilność, jak i historyczną traumę, która nie może zostać inaczej wypowiedziana[73]. W tym miejscu ponownie docieramy do przestrzeni filmowej i jej niebagatelnego znaczenia w konstruowaniu melodramatyzmu. Otóż, jak przekonuje badacz, właśnie ekspozycja przestrzeni nabiera wówczas szczególnej intensywności i znaczenia: gdy przeżywający trudności, znajdujący się w zamkniętej przestrzeni diegetycznej i milczący bohaterowie jedynie obserwują swe otoczenie, to na skutek stłumienia innych zewnętrznych oznak afektów ono właśnie staje się „świadkiem” ich cierpienia i losu. Dramaturgiczne napięcie z tym związane wywołuje typową dla melodramatu rodzinnego duszność, poczucie uwięzienia, potrzasku lub opresji[74]. Widz współodczuwa zatem - za pośrednictwem specyficznej inscenizacji - stan przeżywany przez bohatera; widz także jest wszak zmuszony milcząco patrzeć na te same wnętrza i dekoracje. Dzieje się tak w wielu scenach opisywanych przeze mnie filmów: w pokojach i na korytarzach komisariatu, po których wędruje zrezygnowany Cristi; w hotelowym pokoju służącym za miejsce do przeprowadzenia nielegalnej aborcji; w zagraconym mieszkaniu bezradnego pacjenta, które następnie zamienione zostanie na niemal puste wnętrze przestarzałej karetki i rozświetlone sale przyjęć. Tym samym, niezależnie od bardziej ironiczno-groteskowego (Corneliu Porumboiu, Cristi Puiu) lub patetyczno-dramatycznego (Cristian Mungiu) rysu autorskiego, dzięki szczególnej roli przewidzianej dla przestrzeni filmowej i sposobów jej kreowania, filmy nowej fali kina rumuńskiego ujawniają swą melodramatyczną stronę, będącą rewersem ich minimalistycznego uformowania.

Batori A., Space in Romanian and Hungarian Cinema, Cham 2018

Deaca M., Kitchen encounters: scenes of face-to-face dialogue in films of the new Romanian cinema, [w:] The New Romanian Cinema, red. Ch. Stojanova, D. Duma, Edinburgh 2019, s. 197-210 
Elsaesser Th., Opowieści wściekłości i wrzasku. Uwagi o rodzinnym melodramacie, przeł. S. Bobowski, „Studia Filmoznawcze” 2008, nr 29, s. 11-39

Filimon M., Cristi Puiu, Urbana, Chicago, Springfield, 2017

Foucault M., Nadzorować i karać. Narodziny więzienia, przeł. T. Komendant, Warszawa 1998

Gandhi L., Teoria postkolonialna. Wprowadzenie krytyczne, przeł. J. Serwański, Poznań 2008

Jarzyńska K., Postsekularyzm - wyzwanie dla teorii i historii literatury (rozpoznania wstępne), „Teksty Drugie” 2012, nr 1-2 (133-134), s. 294-307

Kalbarczyk K., Tango z tradycja, „Ekrany” 2017, nr 1 (35), s. 38-39

Kligman G., Polityka obłudy. Kontrola rozrodczości w Rumunii pod rządami Ceaușescu, przeł. P. Art, Kraków 2010

Kunze Th., Ceaușescu. Piekło na ziemi, przeł. J. Czudec, Warszawa 2016

Pethö Á., Exhibited space' and intermediality in the films of Corneliu Porumboiu, [w:] The New Romanian Cinema, red. D. Stojanova, D. Duma, Edinburgh 2019, s. 65-79

Pop D., Making and breaking the new wave canon in Romanian Cinema, [w:] Cultural Studies Approaches in the Study of Eastern European Cinema. Spaces, Bodies, Memories, red. A. Virginás, Cambridge 2016, s. 268-287

Pop D., Romanian New Wave Cinema. An Introduction, Jefferson 2014.

Stachówna G., Niedole miłowania. Ideologia i perswazja w melodramatach filmowych, Kraków 2001

Steffen J., The Cinema of Sergei Parajanov, Madison 2013

Stojanova Ch., Introduction, [w:] The New Romanian Cinema, red. Ch. Stojanova, D. Duma, Edinburgh 2019, s. 1-20

Syska R., (Re)konstruowanie pamięci o Rewolucji w nowym kinie rumuńskim, „Images. The International Journal of European Film, Performing Arts and Audiovisual Communication" 2015, vol. XVII, nr 26, s. 5-14

Szpulak A., Z duchami przodków wzdłuż południka. Filmowo-literacka „Via Carpathia”, <nowynapis.eu/tygodnik/nr-26/artykul/z-duchami-przodkow-wzdluz-poludnika-filmowo-literacka-carpathia>, dostęp: 4.04.2020

Trocan I., Minimalism in the new Romanian cinema: absent, omnipresent or misjudged?, [w:] The New Romanian Cinema, red. Ch. Stojanova, D. Duma, Edinburgh 2019, s. 36-49

Turcuş C., Paradigms of rememoration in postcommunist Romanian cinema, [w:] Cultural Studies Approaches in the Study of Eastern European Cinema. Spaces, Bodies, Memories, red. A. Virginás, Cambridge 2016, s. 216-244

Uricaru I., No Melo: minimalism and melodrama in the new Romanian cinema, [w:] The New Romanian Cinema, red. Ch. Stojanova, D. Duma, Edinburgh 2019, s. 50-62

Virginás A., Fragile diegetic spaces and mobile women: coping with trauma in Hungarian and Romanian films, [w:] Cultural Studies Approaches in the Study of Eastern European Cinema. Spaces, Bodies, Memories, red. A. Virginás, Cambridge 2016, s. 66-84

Virginás A., Traces of genre in new Romanian cinema: A narrow path for a small entity?, [w:] The New Romanian Cinema, red. Ch. Stojanova, D. Duma, Edinburgh 2019, s. 180-193 